\title{
OBSERVATIONS ON DROUGHT DAMAGE TO SOME NATIVE PLANT SPECIES IN EUCALYPT FORESTS AND WOODLANDS NEAR HOBART, TASMANIA
}

\author{
by J.B. Kirkpatrick and F. Marks
}

(with three tables and five text-figures)

\begin{abstract}
KIRKPATRICK, J.B. and MARKS, F., 1985 (31:vii): Observations on drought damage to some native plant species in eucalypt forests and woodlands near Hobart, Tasmania. Pap. Proc. R. Soc. Tasm. 119:15-21. https:// doi.org/10.26749/rstpp.119.15 ISSN 0080-4703. University of Tasmania, Hobart, Tasmania, Australia, 7000.

A large number of shrub and tree species suffered damage in the Ridgeway and University Reserves near Hobart, Tasmania during a prolonged drought. Damage was largely confined to shallow soils and gully margins on dolerite, there being little or no damage on equivalent sites on sedimentary substrata. Intraspecific damage was inversely related to the heights of individuals for particular sites. Relative drought resistance is presented diagrammatically for 24 small shrub species and 17 tall shrub and tree species. Drought damage does not directly limit the distribution of most species observed in this study, although the patterns of relative drought resistance accord well with species distribution in respect to available water.
\end{abstract}

Key Words: Drought resistance, eucalypt forest, eucalypt woodland.

\section{INTRODUCTION}

Droughts, although generally unwelcome and destructive, do have some positive aspects. Like fires, floods, freezes and tempests they may provide valuable evidence of the degree and nature of the impacts of environmental factors on species distributions, providing insights almost impossible to attain under controlled laboratory conditions or from field experiment. The relative degrees of drought da mage and mortality of intermixed species may provide the opportunity for a definite test of ecological hypotheses based on other evidence. These damage and mortality data may also suggest new hypotheses a menable to testing. Parker (1969) has reviewed some of the northern hemisphere literature on the effects of drought on vegetation. In Australia studies of drought effects on native vegetation include those of Pook, Costin and Moore (1966), Kirkpatrick (1970), Ashton, Bond and Morris (1975), Sinclair (1980) and Hnatiuk and Hopkins (1980).

This paper records the relative damage experienced by a large number of shrub and tree species in the foothills of Mt Wellington, Tasmania during the summer of $1982 / 83$ after several years of drought. The environmental correlates of this damage are also recorded, and the above data are used to test the hypotheses that plant species ranges are limited by uncommon rather than common environmental events, and that the relative distributions of different taxa in relation to available soil moisture reflect relative fitness in relation to drought.

\section{METHODS}

\section{Measurement and analysis of environmental variables}

Data from the Hobart Waterworks ( $42^{\circ} 55^{\prime} \mathrm{S}$ $147^{\circ} 17^{\prime} \mathrm{E}, 160 \mathrm{~m}$ above sea level) were used to assess the severity of the drought in the period $1976 / 77$ to $1982 / 83$ in relation to mean and medium rainfall for the period 1897-1982.

Soil depth to $0.6 \mathrm{~m}$ was measured over northsouth transects on dolerite, mudstone and sandstone within the Waterworks Reserve, using a soil auger.

Contiguous $1 \times 1 \mathrm{~m}$ quadrats for plants less than $2 \mathrm{~m}$ tall and $1 \times 5 \mathrm{~m}$ quadrats for plants more than $2 \mathrm{~m}$ tall were placed in a transect from the north to the south face of the dolerite hill between the upper and lower reservoirs in the Waterworks Reserve.

All identifiable taxa of higher plants present within each quadrat were recorded. Incident solar radiation for June, December and the year were calculated for the central quadrat of each group of five quadrats using data for slope and aspect and the graphs of Nunez (1983).

\section{Recording and analysis of relative damage}

During the autumn of 1983 the Waterworks Reserve and the University of Tasmania property were thoroughly traversed in search for situations where four or more individuals of one species exhibited greater than $10 \%$ leaf necrosis and were 


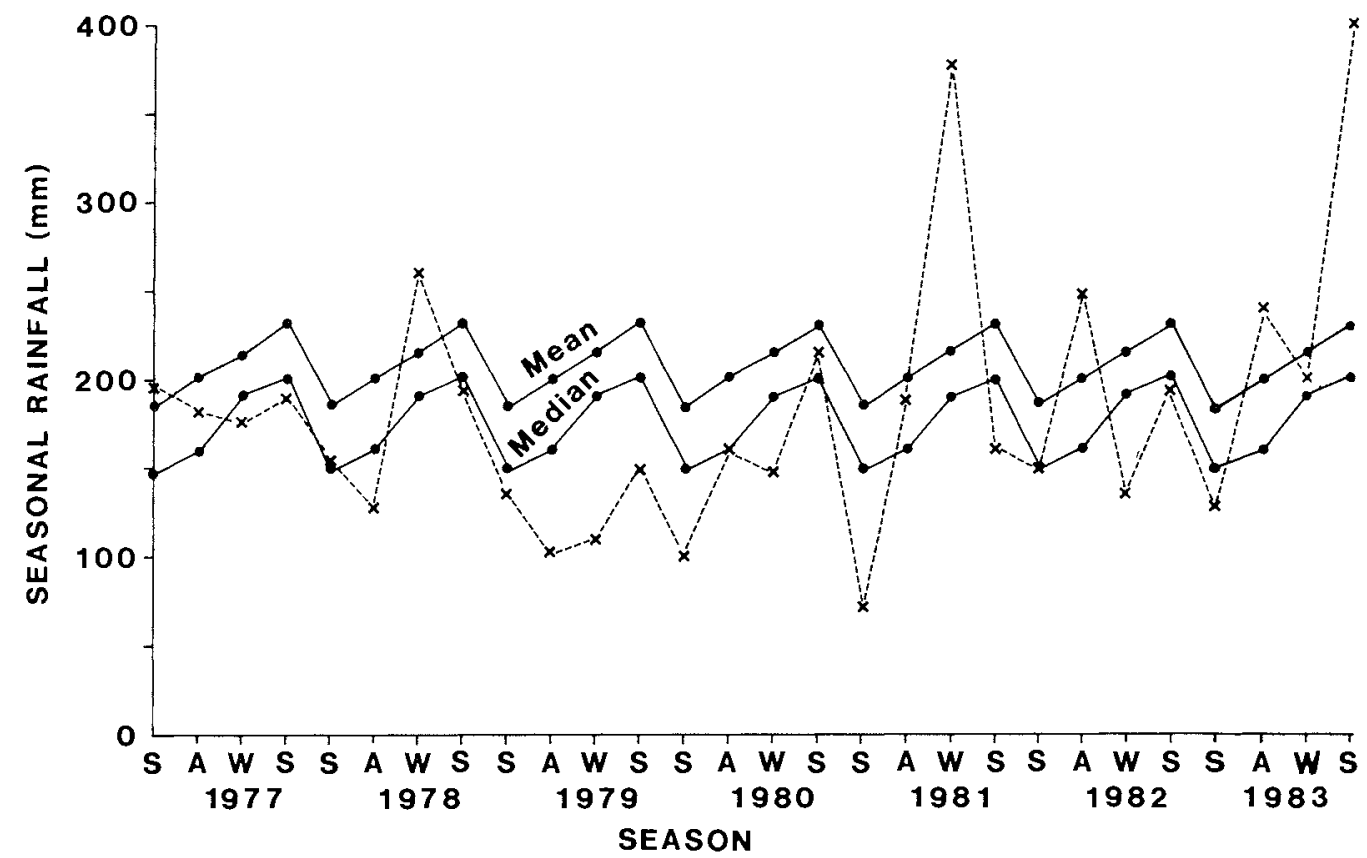

FIG. 1 - Mean and median seasonal rainfall for the period 1897-1982 for the Hobart Waterworks ( $42^{\circ} 55^{\prime} \mathrm{S} 147^{\circ} 17^{\prime} \mathrm{E}, 160 \mathrm{~m}$ above sea-level, mean annual rainfall $834 \mathrm{~mm}$, median annual rainfall $819 \mathrm{~mm}$ ), compared with seasonal precipitation from the summer of $1976 / 77$ to the summer of $1982 / 83,(\quad \ldots--X)$.

mixed with four or more individuals of another species exhibiting no such da mage. The individ uals of both species had to be of similar height, and the mixture had to occur within an homogeneous environment, the distance between individuals usually being less than $0.5 \mathrm{~m}$ but being up to $6.0 \mathrm{~m}$ in the case of a comparison involving badly damaged tall adult individuals of Eucalyptus viminalis, and E. pulchella. Comparisons were made across slope, upslope and downslope of the damaged individuals, but no species to species comparison was used where the damaged individuals were consistently on shallower soils or upslope of the unda maged individuals.

Randomly located $1 \mathrm{~m}$ wide belt transects were placed through mixed species eucalypt regrowth from the 1967 fire. Leaf damage for each individual eucalypt was estimated to the nearest $10 \%$ and height was measured to the nearest $0.01 \mathrm{~m}$.

\section{RESULTS}

\section{The drought}

Eastern Tasmania was one of the regions most severely affected by the drought that commenced in the late 1970's. In the Waterworks area almost all the seasons in the period between and including the autumn of 1977 and the summer of $1982 / 83$ had less than the mean rainfall and most had less than the median rainfall (figure 1). Above average rainfall was confined to two winters and one autumn, and only one summer received between the medium and the mean. The rainfall deficit for this period was $945 \mathrm{~mm}$.

\section{Soils}

The soils formed on north-facing slopes on dolerite are generally shallower than those formed on mudstone, which are in turn generally shallower than those formed on sandstone (figure 2). The underlying sandstone and mudstone is also much more broken and permeable than the dolerite bed rock. The measurements of Robinson (1979) showed that the soils formed on dolerite have a finer texture than those on the other two rock types, and hold water at a greater tension for any percentage moisture content.

\section{Vegetation}

There is continuous floristic variation from the north to the south facing slope on dolerite 

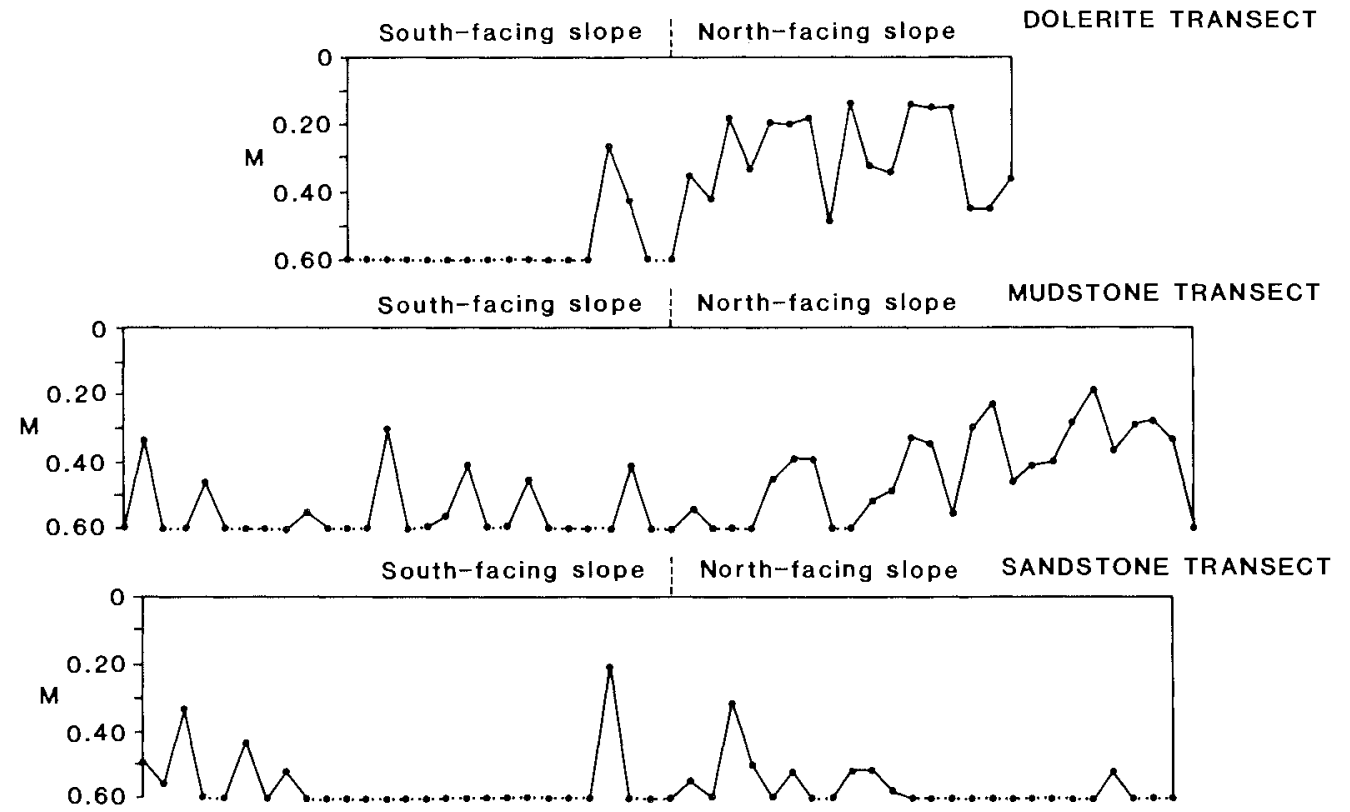

FIG. 2 - Soil depth data along transects across dolerite, sandstone and mudstone hills in the Waterworks Reserve.

(figure 3). Incident solar radiation, and thus moisture availability (Kirkpatrick and Nunez 1980), decreases from the north to the south of the transect.

\section{The locations of damage}

Damage and death were largely confined to shallow $(<0.2 \mathrm{~m})$ soils on northerly aspects or to the margins of wet gullies. No species was observed to be drought-damaged throughout its entire environmental range in the area. In fact, damage was almost totally confined to the brown soils formed on dolerite, despite the presence of a similar range of topographic environments on the adjacent podzolic soils on both mudstone and sandstone. Damage was most common where the regrowth from the intense 1967 fire had escaped later biomass reduction burns.

\section{Relative drought damage}

Within stands of regrowth eucalypts, the most damaged individuals tended to be the smallest (table 1). Figures 4 and 5 illustrate the relative drought resistance of all tree and shrub species which were observed to occur in an undamaged state in intimate mixture with da maged individuals of another species.

Any species was less damaged than those linked to it by downward lines in the figures. Thus, figure 4 shows that Bedfordia salicina was less susceptible to drought damage than all of Acacia melanoxylon, Leptospermum scoparium, Goodenia ovata, Pomaderris pilifera, Acacia myrifolia. Epacris impressa and Pultenaea daphnoides. It was more susceptible to drought damage than Correa reflexa, Dodonaea viscosa, Casuarina stricta and Helichrysum scutellifolium. It may be more or less or equally susceptible to drought damage than the other species in the diagram.

All direct linkages in the diagrams (e.g. Bedfordia salicina to Acacia melanoxylon, figure 5) have a probability of 0.01 or less of occurring by chance (Fisher's exact test). The indirect comparisons (e.g. Bedfordia salicina being less prone to drought damage than Eucalyptus obliqua of the same size) are not all supported by direct field evidence (tables 2 and 3). However, they are based on the logical chain that if $a$ is greater than $b$, and $b$ is greater than $\mathrm{c}$, then a is greater than $\mathrm{c}$.

\section{DISCUSSION}

The relative susceptibility to drought damage of the tree and shrubs species included in figures 4 and 5 does largely reflect their relative distributions both in relation to precipitation over their natural range and the more local variations in moisture availability controlled by the varying incidence of solar radiation in hilly areas. For example, seven of the species on the direct line between Eriostemon 
verrucosus and Pultenaea daphnoides in figure 5 were also recorded in figure 3 , where they have almost exactly the same distribution patterns that could be expected to result from their relative susceptibilities to drought damage (Spearman's $r=$ $0.93, \mathrm{p}<0.01)$. Thus, the species that are least susceptible to drought damage at any particular level of moisture availability do tend to occur on the driest sites, from which the more susceptible species are absent

Although relative susceptibility to drought damage appears to be a good predictor of geographic range, the direct impact of the drought on species distribution patterns appears to be minimal dieback being patchy, and seld om complete for any species within a patch. Many species that suffered damage on the dolerite soils were absent from the drier parts of the adjacent sandstone and mud stone slopes, but exhibited no damage in any part of their range on these rock types. No species was damaged over all of its range on dolerite, and many of the species observed to suffer da mage did not evince it in the topographically driest part of their range of this substratum. Rather, the damage was manifested where soils were particularly shallow and competition for moisture especially fierce. Biomass reduction burning within the previous half decade prevented any severe drought damage.

Most of the species included in figures 4 and 5 recover vegetatively from fire, and exhibit poor survival of germinates except after fires of high intensity. Thus, distribution patterns are largely fixed by events that occur after severe fires. Individuals establishing after a high intensity fire will be greeted by an edaphic environment with considerably more moisture than would otherwise be the case, because of the severe reductions in transpiration that result from the thermal death of all photosynthetic organs. However, despite the relatively high moisture contents of the post-fire soils, the individual germinate is likely to experience more severe drought stress than at any other time in its lifecycle, as its roots will not have penetrated to the moisture stores at depth, but rather will be within the upper part of the soil where evaporative losses through ca pillary movement occur. On sites receiving little or no moisture through lateral movement it is only where rock, rather than soil and moisture, is met close below the capillary fringe that an individual plant is likely to encounter more severe stress than occurs in its early days. The death of adult Eucalyptus obliqua on the margins of its distribution on relatively deep soil in gullies may occur as the result of the severe reduction in downslope movement of moisture that is likely to occur during warm season drought. In this situation the impact of drought on soil moisture stores is likely to be magnified by a failure of summer rains, as with the drought damaged trees noted by Pook, Costin and Moore (1966) on Black Mountain.

Thus, at least within the study area, the catastrophe of drought is relatively unimportant in fixing shrub and tree species distributions, although patterns of moisture availability are reflected in the species composition of the vegetation.

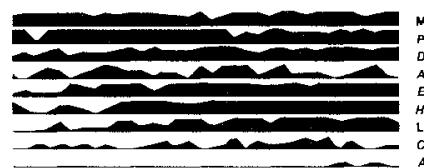

Moss Pot app. Acacio deatbata. Eucatyptus putchoha
Haloragis tetragyna
Lehen Cazex breviculmis
Acacia myrtifolia Acacia myrtifolis

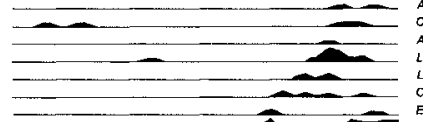


inum marginale Coprosma quadrifida xocarous cupressttorm

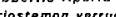
Bulbine sulbosa Lopterynctios unearis -opldosperms ine are var. ino Hellichrysum soiculatum
Ofarria aricoides Schoenus apogon Opercutaria varia aucopogan virgatus Tetrathec s pitosa
Daviesio uictiolia Bossia a prostrata Themedo australis Leptorynchos squamat aodenis tarata
Astrgloma thumfus Lissanthe strigosa
Lipation stipa spp. Pimelia humilis Centaurium erythraea Heflehrysum scorpioides Hypericum gramineum Senecio spp. Acaens ovina
Eucalyptus viminalis Wahtenbergie epp. Lomandrs longifolis arthropodium mitrefloru Diplarrena morae
prasophyflum $9 \mathrm{pD}$. Oxalis cornicutara Leptospermum scopariem Laginifera stipitata Vlola hederacea
Epacris impressa Oleerio erubescens Hypocheris redic Cossinia aculeats
Bedfordfa tinearis

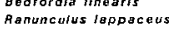
pimelia linitotia Helichrysum dendroideu Banksio marginata
Olearis argo hyyta Olearia argophysa
Olearia ramulosa Dianella tasmanica Eucalyotus obliqua Lomatia finctori
Galium ap. Gatium ap.
Serecio linearitoitios Prerostytis spd. Getanitum spp.
Acacis stricta Acacia stricta Sivlidiam graminjerium
Hatoragis teucrioides Haloragrs reucrio
Othergramineae Pultenaga iunipering



metaes

FIG. 3 - Species distribution and frequency across a dolerite hill in the Waterworks Reserve. 


\section{TABLE 1 \\ MEANS AND STANDARD DEVIATIONS OF SEEDLING HEIGHT (METRES) BY SPECIES AND DROUGHT DAMAGE CLASS}



Table 2

Relative Drought Damage of Species in the Small Shrub Stratum

\begin{tabular}{ll}
\hline Helichrysum scutellifolium $(\mathrm{Hs})$ & $\mathrm{Cs}, \mathrm{Dv}, \mathrm{Cr}, \mathrm{Dc}, \mathrm{Ah}, \mathrm{Bs}, \mathrm{Pp}$ \\
Casuarina stricta $(\mathrm{Cs})$ & $\mathrm{Dv}, \mathrm{Lv}, \mathrm{Ag}, \mathrm{Ah}, \mathrm{Bs}, \mathrm{Pj}, \mathrm{Ls}, \mathrm{Go}, \mathrm{Pp}$ \\
Dodonaea viscosa $(\mathrm{Dv})$ & $\mathrm{Cr}, \mathrm{Ag}, \mathrm{Bs}, \mathrm{Ls}, \mathrm{Pd}, \mathrm{Pp}$ \\
Correa reflexa $(\mathrm{Cr})$ & $\mathrm{Oe}, \mathrm{Bs}, \mathrm{Go}$ \\
Eriostemon verrucosus $(\mathrm{Ev})$ & $\mathrm{Hr}, \mathrm{Lv}, \mathrm{Ag}, \mathrm{Ah}, \mathrm{Lst}, \mathrm{As}, \mathrm{Pj}$ \\
Hibbertia riparia $(\mathrm{Hr})$ & $\mathrm{Lv}, \mathrm{Ag}, \mathrm{Ah}, \mathrm{Lst}, \mathrm{Du}$ \\
Dillwynia cinerascens $(\mathrm{Dc})$ & $\mathrm{Pj}, \mathrm{Ei}, \mathrm{Pd}, \mathrm{Pp}$ \\
Olearia ericoides $(\mathrm{Oe})$ & $\mathrm{Lv}, \mathrm{Pj}$ \\
Leucopogon virgatus $(\mathrm{Lv})$ & $\mathrm{Ag}, \mathrm{Ah}, \mathrm{Lst}, \mathrm{As}, \mathrm{Du}, \mathrm{Pj}, \mathrm{Pp}$ \\
Acacia genistifolia $(\mathrm{Ag})$ & $\mathrm{Ah}, \mathrm{Lst}, \mathrm{As}, \mathrm{Du}, \mathrm{Ei}, \mathrm{Am}$ \\
Astroloma humifusum $(\mathrm{Ah})$ & $\mathrm{Du}, \mathrm{Ls}, \mathrm{Ei}, \mathrm{Pd}, \mathrm{Go}, \mathrm{Pp}$ \\
Lissanthe strigosa $(\mathrm{Lst})$ & $\mathrm{Du}$ \\
Bedfordia salicina $(\mathrm{Bs})$ & $\mathrm{Amn}, \mathrm{Go}$ \\
Acacia stricta $(\mathrm{As})$ & $\mathrm{Pj}, \mathrm{Bm}$ \\
Daviesia ulicifolia $(\mathrm{Du})$ & $\mathrm{Pj}$ \\
Pultenaea juniperina $(\mathrm{Pj})$ & $\mathrm{Amn}, \mathrm{Ls}, \mathrm{Pd}, \mathrm{Go}$ \\
Banksia marginata $(\mathrm{Bm})$ & \\
Acacia melanoxylon $(\mathrm{Amn})$ & $\mathrm{Ls}, \mathrm{Go}, \mathrm{Pp}$ \\
Leptospermum scoparium $(\mathrm{Ls})$ & $\mathrm{Ei}, \mathrm{Pd}$ \\
Epacris impressa $(\mathrm{Ei})$ & $\mathrm{Pd}$ \\
Pultenaea daphnoides $(\mathrm{Pd})$ & \\
Goodenia ovata $(\mathrm{Go})$ & \\
Pomaderris pilifera $(\mathrm{Pp})$ & \\
Acacia myrtifolia $(\mathrm{Am})$ & \\
Species shown by name in the first column sustained less damage than those shown by initials in the same \\
row.
\end{tabular}
row. 
Table 3

Relative Drought Damage of Species in the Tree and Tall Shrub Strata

\begin{tabular}{ll}
\hline Casuarina stricta $(\mathrm{Cs})$ & $\mathrm{Ec}, \mathrm{Dv}, \mathrm{Ami}, \mathrm{Bs}, \mathrm{A}$ \\
Exocarpos cupressiformis $(\mathrm{Ec})$ & $\mathrm{Ami}, \mathrm{Eg}$ \\
Dodonaea viscosa $(\mathrm{Dv})$ & $\mathrm{Ami}, \mathrm{Bs}, \mathrm{Amn}, \mathrm{Eg}, \mathrm{Bs}, \mathrm{Ad}, \mathrm{Amn}, \mathrm{Ev}$, \\
Bursaria spinosa $(\mathrm{Bsp})$ & $\mathrm{Bs}$ \\
Acacia mearnsii $(\mathrm{Ami})$ & $\mathrm{Ad}, \mathrm{Amn}, \mathrm{Ca}, \mathrm{Eo}$ \\
Bedfordia salicina $(\mathrm{Bs})$ & $\mathrm{Ev}, \mathrm{Ep}, \mathrm{Bm}, \mathrm{Eo}$ \\
Acacia dealbata $(\mathrm{Ad})$ & $\mathrm{Amn}, \mathrm{Av}$ \\
$\begin{array}{l}\text { Pomaderris apetala }(\mathrm{Pa}) \\
\text { Acacia melanoxylon }(\mathrm{Amn})\end{array}$ & \\
Acacia verticillata $(\mathrm{Av})$ & $\mathrm{Eg}, \mathrm{Ep}, \mathrm{Bm}, \mathrm{Eo}$ \\
Eucalyptus viminalis $(\mathrm{Ev})$ & $\mathrm{Oa}, \mathrm{Eo}$ \\
$\begin{array}{l}\text { Eucalyptus globulus }(\mathrm{Eg}) \\
\text { Casuarina littoralis }(\mathrm{Cl})\end{array}$ & $\mathrm{Ep}$ \\
Eucalyptus pulchella $(\mathrm{Ep})$ & $\mathrm{Eov}, \mathrm{Bm}, \mathrm{Eo}$ \\
Eucalyptus ovata $(\mathrm{Eov})$ & \\
Banksia marginata $(\mathrm{Bm})$ & $\mathrm{Eo}$ \\
Olearia argophylla $(\mathrm{Oa})$ & $\mathrm{Ca}$ \\
Cassinia aculeata $(\mathrm{Ca})$ & \\
Eucalyptus obliqua $(\mathrm{Eo})$ &
\end{tabular}

Species shown by name in the first column sustained less da mage than those shown by initials in the same row.
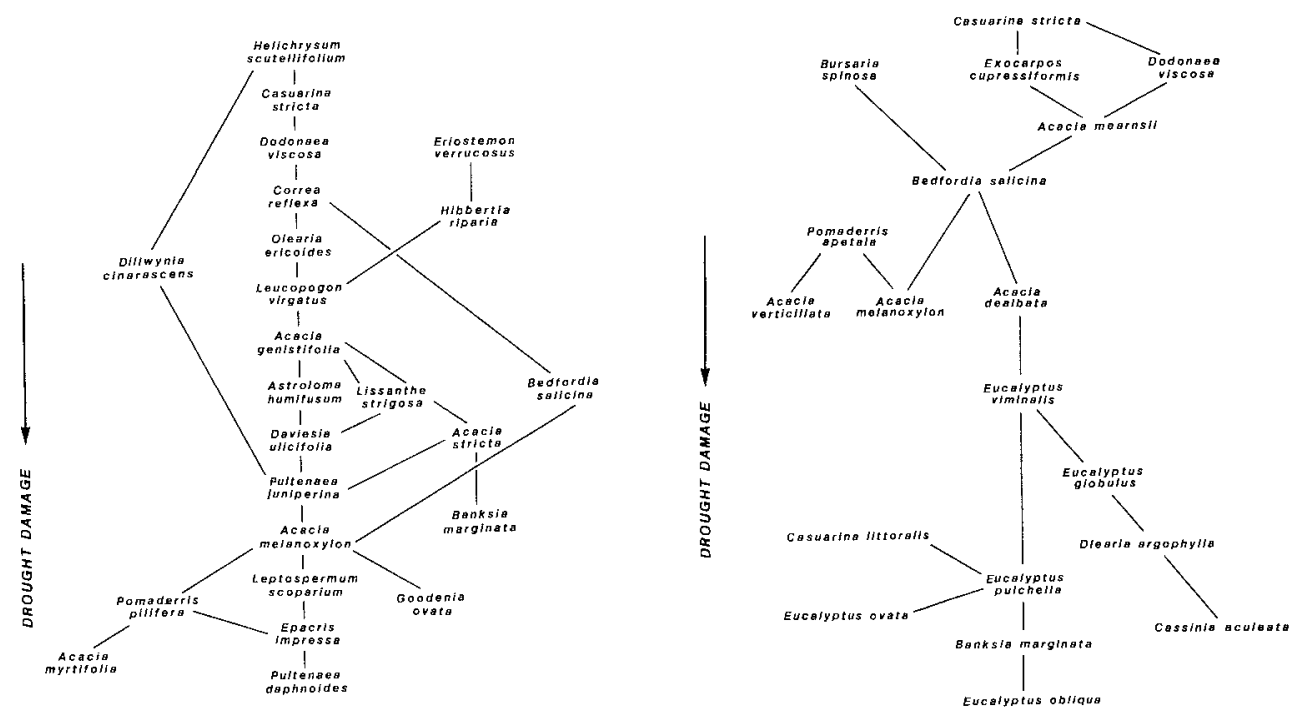

FIG. 4 - Relative drought resistance of shrub species.

FIG. 5 - Relative drought resistance of tall shrub and tree species. 


\section{REFERENCES}

ASHTON, D.H. BOND, H. \& MORRIS, G.C., 1975 Drought damage on Mount Towrong. Victoria. Proc. Linn. Soc. N.S.W., 100: 55-69.

HNATIUK R.J. \& HOPKINS, A.J.M., 1980: Western Australian species-rich kwongan (sclerophyllous shrubland) affected by drought. Aust. J. Bot., 28: 573-585.

KIRKPATRICK, J.B., 1970: Observations of the relative drought resistance of two eucalypt species near Airey's Inlet. Victorian Naturalist, 87: 184-188.

KIRKPATRICK, J.B.\& NUNEZ, M., 1980: Vegetationradiation relationships in mountainous terrain: eucalypt-dominated vegetation in the Risdon Hills, Tasmania. J. Biogeography, 7: 197-208.
NUNEZ, M., 1983: Estimation of solar radiation received on slopes in Tasmania. Pap. Proc. R. Soc. Tasm., 117: 153-159.

PARKER, J., 1969: Further studies of drought resistance in woody plants. The Botanical Review, 35: $317-371$.

POOK, E.W., COSTIN, A.B.\& MOORE, C.W.E., 1966: Water stress in native vegetation during the drought of 1965. Aust. J. Bot., 14: 257-267.

ROBINSON, M.B., 1979: A study into eucalypt ecology. University of Tasmania (unpubl.).

SINCLAIR, R., 1980: Water potential and stomatal conductance of three Eucalyptus species in the Mount Lofty Ranges, South Australia: responses to summer drought. Aust. J. Bot., 28: 499-510.

(accepted Sept. 7, 1984) 